\title{
PERAN DUKUNGAN ORGANISASIONAL, KOMPETENSI TEKNOLOGI DAN LINGKUNGAN EKSTERNAL DALAM RANGKA MENDORONG PENGADOPSIAN E-COMMERCE PADA USAHA KECIL MENENGAH
}

\author{
Audita Nuvriasari \\ Fakultas Ekonomi Universitas Mercu Buana Yogyakarta \\ e-mail: audy_nuvriasari@ymail.com
}

\begin{abstract}
Abstarct
Electronic commerce (e-commerce) is one of the most discussed topics in business today. It is not only in large scale business but also in small medium enterprises (SMEs). E-commerce is a paradigm shift that is radically changing traditional ways of doing business. The adoption of $e$ commerce has been widely analyzed in various reserachs. The purposes of this research are to identify the factors that hamper and support SMEs to adopt E-commerce and to analyze the influence of organizational support, the competency of technogy and external environtment to ecommerce adoption in SMEs. The sampe size of this research is 34 SMEs in Moyudan District, DIY which use information technology (internet) in their business. This research uses a descriptive and inferential method to solve the research problems. Based on descriptive method can be identified that the main objective of SMEs to use the internet in their business activities is to find business information (97.1\%). While the main constraints faced by SMEs in adopting e-commerce is the limited human resource capacity and skills on information technology (70.6\%). The main benefits obtained by SMEs adopt e-commerce in order to support its business activities are accelerating access to business information (85.3\%). The other results of this research explain that organizational support, the competency of technogy and external environtment have significant positive effect to e-commerce adoption in SMEs.
\end{abstract}

Keywords: e-commerce adoption, organizational support, technology competence, external environment

\begin{abstract}
Abstrak
Perdagangan berbasis elektronik (e-commerce) dewasa ini menjadi salah satu topik yang banyak didisukusikan dalam dunia binis. Tidak hanya bagi bisnis skala besar akan tetapi juga bagi Usaha Kecil Menengah (UKM). E-commerce merupakan pergeseran paradigma yang menggubah secara radikal terhadap cara konvensiaonal dalam berbisnis. Tujuan dari penelitian ini adalah untuk mengdisentifikasi faktor-faktor yang menjadi kendala dan pendorong bagi UKM dalam mengadopsi e-commerce dan untuk mengetahui pengaruh dari dukungan organisasional, kompetensi teknologi dan lingkungan eksternal terhadap pengadopsian e-commerce. Jumlah sampel penelitian sebanyak 34 UKM yang ada di wilayah Moyudan, DIY yang telah menggunakan teknologi informasi (internet) dalam kegiatan bisnisnya. Penelitian ini menggunakan metode deskriptif dan inferensial untuk memecahkan permasalahan penelitian. Berdasarkan hasil analisis deskriptif dapat ditunjukkan bahwa tujuan utama UKM menggunakan internet dalam kegiatan bisnisnya adalah untuk pencarian informs bisnis $(97,1 \%)$. Sedangkan faktor utama yang menjadi penghambat bagi UKM dalam mengadopsi e-commerce adalah keterbatasan kemampuan dan ketermpilan sumber daya manusia dalam penguasaan teknologi informasi $(70,6 \%)$. Manfaat utama yang diperoleh UKM dengan pengadopsian e-commerce dalam menjalankan kegiatan bisnisnya adalah dapat dengan mudah mengakses informasi bisnis $(85,3 \%)$. Hasil lain dari penelitian ini menjelaskan bahwa terdapat pengaruh yang positip dan signifikan antara dukungan organisasional, kompetensi teknologi dan lingkungan eksternal terhadap pengadopsian $e$-commerce.
\end{abstract}

Kata Kunci: e-commerce, dukungan organisasional, kompetensi teknologi, lingkungan eksternal 


\section{PENDAHULUAN}

E-commerce merupakan penggunaan satu set dinamis teknologi, aplikasi, dan proses bisnis yang menghubungkan perusahaan, konsumen, dan komunitas tertentu melalui transaksi elektronik dan perdagangan barang, pelayanan dan informasi yang dilakukan secara elektronik. $E$ commerce menjadi salah satu sarana penting dalam dunia perdagangan pada umumnya baik dalam kegiatan pemasaran maupun penjualan produk dan jasa. Perkembangan ini didorong dengan semakin berkembangnya teknologi informasi di berbagai sektor dan banyaknya masyarakat yang mengakses internet. Dalam Warta UKM (2012) dijelaskan bahwa di era globalisasi ini, internet sudah bukan lagi sesuatu yang mewah bagi masyarakat Indonesia dimana sekitar 130 juta masyarakat mengakses internet melalui ponsel untuk mencari toko dan layanan lokal, seperti informasi seputar hiburan, tempat makan, berita, atau informasi untuk berbelanja. Dari jumlah itu, lebih dari 40 juta orang menggunakan internet secara rutin setiap hari.

Meskipun banyak masyarakat yang mengakses internet, akan tetapi teknologi ini masih sangat minim dimanfaatkan oleh UKM. Hanya sedikit pelaku UKM di Indonesia yang sadar bahwa penguasaan teknologi informasi (TI) dapat membuka peluang lebih lebar bagi usaha mereka. Seperti dikutip dari www.tribunnews.com (2012) dijelaskan bahwa Badan Pusat Statistik (BPS) mencatat hanya ada 75,000 dari sekitar 17 juta UKM di Indonesia yang memiliki website Fakta itu menjadikan daya saing rata-rata pelaku UKM di Tanah Air kian rendah ditambah dengan semakin ketatnya kompetisi terutama dalam menghadapi perusahaan besar dan pesaing modern lainnya. Perkembangan teknologi yang semakin pesat justru telah menempatkan UMKM pada posisi yang kurang menguntungkan. Hal itu karena sebagian besar UKM menjalankan usahanya dengan cara-cara tradisional, termasuk dalam produksi dan pemasaran. Perlu disadari bahwa penggunaan teknologi akan sangat membantu UKM untuk bisa lebih berkembang. Laporan dari Deloitte Access Economics: "The Connected Archipelago: The Role of the Internet in Indonesia's Economic Development" seperti yang dikutip dari Marketeers (2012) menemukan bahwa dari survey terhadap
200 pelaku UKM Indonesia, rata-rata 29\% dari pendapatan per tahun mereka datang dari aktivitas online mereka.Pemanfaatan dunia online bagi UKM dapat dilakukan dengan berbagai cara seperti dengan membuka website meng ikuti social media, dengan memanfaatkan search engine optimization.

Berdasarkan hasil penelitian Nuvriasari dan Hadiyati (2008) dapat dijelaskan bahwa dalam proses bisnis internal terkait dengan pemanfaat teknologi informasi pada UMKM di DIY masih terdapat $38,3 \%$ pelaku UMKM yang belum menggunakan piranti teknologi informasi dalam menunjang kegiatan bisnis mereka dan terdapat $18,3 \%$ pelaku UMKM yang ingin menggunakan tetapi terkendala pada permasalahan dana untuk pengadaan piranti teknologi informasi. Dalam pemanfaat teknologi informasi dalam hal ini adalah internet untuk memasarkan produk dapat ditunjukkan bahwa sebagian besar pelaku UMKM $(43,3 \%)$ belum memanfaatkan piranti tersebut untuk memasarkan hasil produknya. Disamping itu sebagian besar pelaku UMKM $(71,7 \%)$ belum memanfaatkan internet untuk mencari informasi pasar. Sebagian besar pelaku UMKM $(75 \%)$ belum memanfaatkan internet untuk berkomunikasi dengan pemasok maupun pelanggan.

Minimnya UKM yang mengadopsi teknologi informasi dalam menjalankan bisnisnya berdasarkan sejumlah penelitian di beberapa negara berkembang termasuk di Indonesia pada umunya lebih dikarenakan isolasi yang menghambat akses UKM kepada pasar, informasi, modal, keahlian, dan dukungan institusional. Penelitaian yang dilakukan oleh Huniati et al. (2009) menunjukan bahwa faktor yang menjadi kendala dalam mengadopsi $e$ commerce di Negara berkembang (Lybia) adalah: mahalnya biaya pemanfaatan internet, ketidaksesuaian layanan pembelanjaan online dengan budaya masyarakat, dan keterbatasan kepercayaan masyarakat terhadap system perdagangan online. Di negara maju seperti Inggris, faktor yang menjadi kendala dalam pengadopsian teknologi informasi antara lain adalah keengganan pelaku bisnis untuk menerima perubahan teknologi informasi, ketidaksiapan memasuki pasar global, keterbatasan keterampilan dalam TI, keterbatasan SDM dan sumber daya pendukung, biaya, keterbatasan 
pengetahuan, kerumitan dalam pemanfaatan IT (Simpson and Docherty, 2004).

Kendala-kendala yang dialami oleh pelaku UKM di Indonesia perlu diatasi dengan perlunya dukungan dari sejumlah pihak khususnya pemerintah. Mengingat dengan pemanfaatan e-commerce akan memberikan banyak keuntungan bagi UKM seperti: memperpendek jarak antara pelaku bisnis dengan konsumen, memperluas jangkauan pasar dimana tidak ada lagi batasan-batasan secara geografis, perluasan jaringan mitra bisnis dengan mengetahui secara geografi konsumenkonsumen potensial, dan meningkatkan efisiensi dimana akan memangkas biaya-biaya operasional yang ditimbulkan. Menurut Google Country Lead, Public Policy and Government Affairs Southeast Asia, Mike Orgill seperti yang dikutip dari www.tribunnews.com (2012) menjelaskan bahwa kontribusi internet terhadap pendapatan domestik bruto Indonesia akan meningkat dari 1,6\%, menjadi 2,5\% dalam lima tahun ke depan. Kontribusi tersebut bisa melebihi yang diberikan minyak dan kayu. Fenomena tersebut sangat didukung oleh pertumbuhan pengguna internet di Indonesia yang terus mengalami peningkatan, terutama pengguna bisnis online dari usaha kecil dan menengah (UKM). Sebagai perbandingan mengenai manfaat internet bagi pertumbuhan bisnis UKM, UKM yang menggunakan internet dapat tumbuh $10 \%$ dibandingkan yang belum menggunakannya.

Mengingat arti penting pemanfaatan $e$ commerce dalam pengembangan bisnis UKM dan sejalan dengan visi Departemen Perindustrian untuk mendorong UKM dalam memanfaatkan teknologi informasi sehingga UKM dapat bersaing di pasar global maka perlu dilakukan pengkajian yang lebih mendalam salah satunya dengan melakukan penelitian mengenai pengadopsian e-commerce oleh UKM dengan mempertimbangkan sejumlah faktor-faktor yang mempengaruhinya. Adapun berdasarkan sejumlah penelitian yang telah dilakukan sebelumnya dapat ditunjukkan bahwa sejumlah faktor pendorong dalam pengadopsian e-commerce oleh UKM antara lain adalah: faktor organisasional, lingkungan internal dan eksternal organisasi, sumber daya teknologi, dan karakteristik e-commerce.

Pokok permasalahan yang diangkat dalam penelitian ini adalah: (1). faktor-faktor apakah yang menghambat dan mendorong dalam pengadopsian e-commerce pada UKM di Kecamtan Moyudan, Kabupaten Sleman, (2). bagaimanakah pengaruh dukungan organisasional, kompetensi teknologi dan lingkungan eksternal terhadap pengadopsian e-commerce baik secara parsial maupun simultan pada UKM di Kecamtan Moyudan, Kabupaten Sleman, dan (3). diantara variabel dukungan organisasional, kompetensi teknologi dan lingkungan eksternal manakah yang dominan berpengaruh terhadap pengadopsian e-commerce pada UKM di Kecamatan Moyudan, Kabupaten Sleman.

\section{KAJIAN PUSTAKA}

\section{Pengertian E-Commerce}

E-Commerce atau Electronic Commerce didefinisikan sebagai proses pelaksanaan transaksi bisnis seperti: distribusi, pembelian, penjualan, dan pelayanan yang dilakukan secara elektronik melalui jaringan komputer terutama internet dan juga jaringan eksternal (Kabanda, 2011). E-Commerce adalah lingkungan digital yang memungkinkan transaksi komersial terjadi diantara banyak organisasi dan individu (Loudon, 2008). E-commerce dapat didefinisikan sebagai penggunaan satu set dinamis teknologi, aplikasi, dan proses bisnis yang menghubungkan perusahaan, konsumen, dan komunitas tertentu melalui transaksi elektronik dan perdagangan barang, pelayanan dan informasi yang dilakukan secara elektronik (Yulimar dan Setiawan, 2008). E-commerce merupakan transaksi pembelian dan penjualan informasi, produk dan layanan melalui jaringan computer atau dengan memanfaatkan teknologi internet seperti e-mail atau intranet untuk bertukar informasi antara perusahaan into sendiri dengan stakeholders eksternal (Huniati et al., 2009).

\section{Manfaat E-Commerce Dalam Kegiatan Bisnis}

Sejumlah peneliti menjelaskan manfaat $e$ commerce dalam kegiatan bisnis khususnya UKM antara lain: memberikan kesempatan yang lebih luas bagi pelaku UKM untuk memasuki pasar nasional dan pasar global yang sebelumnya belum terjangkau, meningkatkan intensitas komunikasi antar pelaku bisnis, meningkatkan perolehan akses informasi, 
meningkatkan dan memperluas pemasaran dan transaksi antara konsumen dan pemasok (Huniati et al., 2009).

Purbo dan Wahyudi (2001) mengatakan bahwa perusahaan yang menggunakan $E$ commerce akan mendapatkan sejumlah manfaat, yaitu: (a). Terbukanya aliran pendapatan baru yang lebih menjanjikan yang tidak bisa ditemui di system transaksi tradisional; (b). Meningkatkan market exposure; (c). Menurunkan biaya operasional; (d). Melebarkan jangkauan, meningkatkan kesetiaan pelanggan, meningkatkan manajemen pemasok; (e) memperpendek waktu produksi dan meningkatkan rantai nilai.

Adapun pemanfaatan teknologi informasi melalui piranti internet dalam bentuk online shop dapat memberikan banyak keuntungan bagi UKM atau home industry, antara lain memperpendek jarak antara pelaku bisnis dengan konsumen, memperluas jangkauan pasar dimana tidak ada lagi batasan-batasan secara geografis, perluasan jaringan mitra bisnis dengan mengetahui secara geografi konsumen-konsumen potensial, dan meningkatkan efisiensi dimana akan memangkas biaya-biaya operasional yang ditimbulkan.

Menurut Alrubaiee et al. (2012) dapat dijelaskan bahwa penerapan e-commerce dalam kegiatan bisnis dapat memberikan banyak manfaat seperti: meningkatkan image perusahaan, membantu dalam pencapaian tujuan bisnis, mengurangi biaya dalam kegiatan bisnis, meningkatkan proses bisnis, meningkatkan produktivitas karyawan, meningkatkan profitabilitas perusahaan, meningkatkan tingkat pengembalian investasi, meningkatkan penjualan tahunan perusahaan, meningkatkan pertumbuhan pangsa pasar, meningkatkan daya saing, meningkatkan hubungan dengan mitra bisnis, dan meningkatkan kinerja bisnis secara menyeluruh.

\section{Pengadopsian E-Commerce}

Menurut Senarathna and Wickramasuriya (2011) menjelaskan bahwa pengadopsian e-commerce dapat diukur melalui semua kegiatan usaha atau bisnis yang dilakukan secara on-line dengan menggunakan teknologi informasi. Tingkat pengadopsian e-commerce dapat dikategorikan pada tingkat yang paling rendah sampai dengan paling tinggi, yakni sebagai berikut:
Level 1: Developers (pengembang/pencari), yakni perusahaan memiliki tingkat terendah dalam pemanfaatan layanan $e$ commerce operasional akan tetapi memiliki tingkat tertinggi dalam pencarian informasi eksternal.

Level 2: Communicator (komunikator), yakni perusahaan telah memanfaatkan $e$ commerce dalam bentuk e-mail untuk berkomunikasi dengan mitra bisnis seperti: pemasok dan konsumen. Mereka juga menggunakan email untuk pertukaran dokumen elektronik dan desain dengan pelanggan dan pemasok

Level 3: Web Presence (Kehadiran Web), yakni perusahaan melakukan semua aktivitas bisnis dan layanannya melalui website Pada tahap ini semua aktivitas bisnis yang dilakukan oleh komunikator (pengadopsi pada level 2) dioperasionalkan melalui website.

Level 4: Transactors (Pelaku Transaksi), yakni perusahaan yang melakukan semua aktivitas bisnis yang dilakukan oleh pengadopsi pada level 3 dan melakukan pengadaan persediaan dari pemasok secara on-line, pemesanan dan pembayaran pembelian persediaan on-line, menerima pembayaran online, menyediakan layanan purna jual secara on-line, rekrutmen on-line dan menerima pesanan on-line.

\section{Faktor-Faktor Yang Mempengaruhi Pengadopsian E-Commerce}

Faktor-faktor yang mempengaruhi pengadopsian e-commerce telah dikemukakan oleh sejumlah peneliti, antara lain Almoawi and Mahmood (2010) yang menjelaskan bahwa faktor yang dapat memberikan pengaruh adalah faktor organisasional, teknologi dan lingkungan. Faktor organisasional meliputi: ukuran organisasi, perilaku pimpinan, tingkat inovasi pimpinan dan pengetahuan pimpinan mengenai inovasi. Faktor teknologi meliputi: manfaat dari pengimplementasian teknologi, kesesuaian teknologi dan tingkat kompleksitas. Sedangkan lingkungan meliputi intensitas persaingan dan intensitas informasi.

Menurut Olatokun and Kebonye (2010) dapat dijelaskan bahwa faktor-faktor yang mendorong UKM untuk mengadopsi teknologi informasi dipengaruhi oleh tekanan faktor eksternal yakni pesaing, konsumen, mitra 
bisnis, media dan publik. Faktor-faktor tersebut dapat memberikan pengaruh secara langsung maupun tidak langsung dalam pengadopsian teknologi informasi. Ukuran usaha juga mempengaruhi dalam pengadopsian teknologi informasi, dimana semakin kecil ukuran usaha maka semakin kecil keinginan untuk memanfaatan Teknologi Informasi. Hal ini dilarenakan keterbatasan atau kelangkaan sumber daya, kendala financial, kemampuan bersaing yang rendah,keterbatasan sumber daya manusia dan lain-lain.

Senarathna and Wickramasuriya (2011) menjelaskan bahwa faktor organisasional yang dapat memberikan pengaruh terhadap pengadopsian e-commerce pada UKM, yakni: (a). budaya organisasi yang terdiri atas jenis budaya organisasi dan karakteristik hirarki budaya, (b) sumber daya teknologi yang terdiri atas: ketersediaan piranti komputer, ketersediaan sumber daya teknis, kepemilikan website, dan metode akses internet, (c). perilaku pimpinan yang merepresentasikan pandangan manager atau pemilik UKM terhadap inovasi.

Menurut Hussin and Noor (2005) dapat dijelaskan bahwa faktor-faktor yang mempengaruhi pengadopsian e-commerce pada UKM di negara berkembang seperti Malaysia antara lain meliputi: (a). manfaat relative yang diterima UKM dengan pengadopsian e-commerce seperti: efisiensi biaya, penjangkauan pasar yang lebih luas, dan lain-lain, (b). kesesuaian (compatibility) yang menunjukkan seberapa tepat inovasi teknologi baru diimplementasikan atau sesuai dengan proses bisnis yang ada pada UKM, (c). kompleksitas (complexity) yang menunjukkan tingkat kerumitan atau kesukaran yang dihadapi UKM dengan mengadopsi e-commerce, (d) kemampuan diujikan (trialability), e-commerce dapat diujikan jika mampu membawa pergeseran atau perubahan dalam bisnis dan adanya dukungan pendanaan untuk mengcover biaya yang besar untuk mulai mengujicobakannya, (e) dapat diobservasi (observability) yang menunjukkan kemampuan untuk melihat hasil manfaat dari pengimplementasian e-commerce. Dalam penelitian Azzam and Quaddus (2009), faktor yang mempengaruhi pengadopsian e-commerce tidak hanya sebatas pada relative benefit, compatibility, complexity, trialability dan observability akan tetapi juga dipengaruhi oleh perceived risk atau resiko yang diterima. Dari hasil penelitian ini dapat ditunjukkan bahwa komppelsitas atau kerumitan dan resiko yang diterima memiliki pengaruh negatif terhadap pengadopsian e-commerce pada UKM. Sementara keseusaian, kemampuan diujikan dan kemampuan diobservasi memiliki pengaruh yang positip terhadap pengadopsian $e$ commerce.

Faktor-faktor yang mempengaruhi UKM dalam mengadopsi e-commerce di negara berkembang adalah sebagai berikut (Salah and Irwin, 2010): a) Faktor Organisasional (Organizational Factors), meliputi: kesadaran (awereness), sumber daya bisnis (Business Resources), dukungan pemilik atau Manajemen (Owner Support), sumber daya manusia (Human resources), keahlian dalam teknologi informasi (IT Expertise), dan sumber daya teknologi (Technology Resources). b). Faktor Eksternal (External Factors), meliputi: kekuatan pasar (market forces), pemerintah (Government), dukungan industri (supporting industries), dan tekanan persaingan (competitive pressure). c) Faktor Inovasi (innovation Factors), meliputi: manfaat relative (relative advantage), kesesuaian (compatibility), biaya (cost), dan citra (image).

Penelitian lain dilakukan oleh Simpson and Docherty (2004) menjelaskan bahwa permasalahan yang seringkali dihadapi oleh UKM di Inggris adalah tingginya biaya untuk mengadopsi e-commerce. Faktor-faktor yang menjadi kendala antara lain: keengganan pelaku bisnis untuk menerima perubahan teknologi informasi, ketidaksiapan memasuki pasar global, keterbatasan keterampilan dalam TI, keterbatasan SDM dan sumber daya pendukung, biaya, keterbatasan pengetahuan, kerumitan dalam pemanfaatan IT dan lain-lain. Sedangkan faktor yang menjadi pendorong bagi pelaku bisnis dalam mengadopsi e-commerce antara lain: meningkatkan daya saing bisnis, komunikasi yang lebih terbuka dalam perdagangan, kesempatan yang lebih besar dalam melakukan inovasi bisnis, manfaatmanfaat lain dari pemanfaatan TI, peningkatan penjualan dan lain-lain.

Penelitian yang dilakukan oleh Yulimar dan Setiawan (2008) menjelaskan bahwa kompatibilitas, dukungan manajemen, kesiapan organisasional, dorongan ekternal, manfaat yang dirasakan memiliki pengaruh yang positip dan signifikan terhadap pengadopsian e-commerce. 
Hasil penelitian ini juga menunjukkan bahwa pengadopsian $e$-commerce mempunyai pengaruh positip dan signifikan terhadap kinerja perusahaan.

\section{METODE PENELITIAN}

\section{Sampel Penelitian}

Responden yang memenuhi kriteria untuk dijadikan sampel dalam penelitian ini sebanyak 34 UKM. Kriteria sampel penelitian adalah UKM yang berada di Kecamatan Moyudan dan telah memanfaatkan internet dalam kegiatan bisninya sesuai dengan skala usaha yang mencakup level pemula atau developers/searchers (pencarian informasi bisnis melalui internet), level communicators (menggunakan e-mail untuk berkomunikasi dan transaksi dokumen dengan mitra bisnis), level web presence (menggunakan website perusahaan untuk smua aktivitas bisnis yang dilakukan pada level communicator) sampai dengan level tertinggi atau transactors (menggunakan website perusahaan untuk semua transaksi bisnis seperti: pembayaran, pemesanan, hubungan $\mathrm{B} 2 \mathrm{~B}$ dan B2C secara on-line).

\section{Variabel Penelitian}

Variabel dukungan organanisasional $\left(\mathrm{X}_{1}\right)$ diadaopsi dan dimodifikasi dari model penelitian sebelumnya yang dikembangkan oleh Senarathna and Wickramasuriya (2011), Almoawi and Mahmood (2010) yang meliputi: ketersediaan sumber finansial, kesiapan menerima resiko dari pemanfaatan e-commerce, komitmen pimpinan, dan kesadaran menerima perubahan dan perkembangan teknologi informasi.

Variabel kompetensi teknologi $\left(\mathrm{X}_{2}\right)$ diadopsi dan dimodifikasi dari penelitian Salah and Irwin (2010), Hussin and Noor (2005) yang meliputi: kemampuan dan keterampilan SDM, ketersediaan piranti teknologi informasi (komputer dan jaringan internet), ketersediaan program dan system pendukung e-commerce (software, website), dan kesesuaian antara manfaat dan biaya dalam penerapan e-commerce.

Variabel lingkungan eksternal $\left(\mathrm{X}_{3}\right)$ diadopsi dan dimodifikasi dari penelitian Salah and Irwin (2010), Yulimar dan Setiawan (2008) yang meliputi: dorongan dan tuntutan dari konsumen, pemasok, perkembangan dunia bisnis, dorongan pemerintah dan tekanan pesaing.
Variabel pengadopsian e-commerce (Y) diadopsi dan dimodifikasi dari penelitian Yulimar dan Setiawan (2008), Huniati et.al (2009), Simpson and Docherty (2004), Alrubaiee et al., (2012), yang meliputi: dukungan seluruh elemen organisasi, kecukupan sumber daya, ketersediaan sarana dan prasarana teknologi informasi, dorongan pihak eksternal, mempermudah akses informasi, meningkatkan kinerja usaha, meningkatkan kualitas dan kecepatan layanan pada mitra bisnis, meningkatkan efisiensi biaya, dan lebih unggul dibanding perdagangan berbasis konvensional.

\section{Metode Pengumpulan Data dan Analisis Data}

Metode pengumpulan data menggunakan observasi, kuesioner dan wawancara terhadap responden penelitian. Metode analisis data menggunakan metode deskriptif yang ditujukan untuk mengidentifikasi faktor-faktor yang menghambat dan mendukung UKM dalam pengadopsian e-commerce dan menggunakan metode inferensial yang ditujukan untuk pembuktian hipotesa penelitian. Dalam penelitian ini alat analisis inferensial menggunakan analisis regresi dan telah memenuhi syarat pengujian asumsi klasik. Pembuktian hipotesa menggunakan uji t dan uji F. Skala pengukuran variabel penelitian menggunakan skala likert berjenjang 5 (sangat tidak setuju sampai dengan sangat setuju) dan terhadap instrument pengumpul data dilakukan pengujian validitas dan reliabilitas. Berdasarkan hasil uji instrument pengumpul data dalam penelitian ini semua butir kuesioner telah memenuhi syarat validitas dan reliabilitas.

\section{HASIL ANALISIS DAN PEMBAHASAN}

\section{Tujuan Penggunaan Teknologi Informasi (Internet)}

Tujuan UKM menggunakan teknologi informasi (internet) dalam menjalankan kegiatan bisnisnya dapat ditunjukkan pada rangkuman tabel 1 .

Berdasarkan tabel tersebut dapat dijelaskan bahwa sebagian besar UKM masih berada dalam level pemula atau developers/searchers yakni memanfaatkan internet dalam kegiatan bisnisnya untuk mencari informasi bisnis. Disamping itu juga berada pada level communicator dimana pelaku bisnis UKM memanfaatan e-mail untuk berkomuni- 
kasi dengan mitra bisnis seperti konsumen dan pemasok. Sedangkan hanya sebagian kecil UKM yang memanfaatkan internet untuk kegiatan bisnis pada level web presence maupun transactors yakni melakukan kegiatan pemasaran on-line, pembayaran, pemesanan produk maupun melakukan kegiatan pemasaran Business to Customer maupun Business to Business secara on-line UKM yang ada pada level web presence maupun transactor secara umum telah memiliki blog atau website sendiri maupun menginduk pada website bisnis seperti: www.indonetwork.co.id, www.BisnisUKM.com.

Dari hasil wawancara dengan beberapa UKM seperti: Sriti Production, O'glek Craft, Wida Craft, Nophi Craft dan Ragil Jaya Craft dapat dijelaskan bahwa tujuan utama menggunakan internet dalam kegiatan bisnis untuk mencari informasi bisnis, seperti produkproduk kerajinan yang saat ini diminati oleh konsumen, informasi pameran yang diselenggarakan oleh instansi pemerintah maupun swasta, contoh desain produk dan lain-lain. Secara umum pelaku bisnis pada UKM menggunakan piranti modem untuk dapat mengakses jaringan internet akan tetapi ada beberapa pelaku bisnis lainnya yang memanfaatkan jasa warnet. Pelaku bisnis UKM juga melakukan komunikasi dengan sejumlah konsumen ataupun calon buyer melalui e-mail, hal ini dinilai cukup mempermudah dan memperjelas komunikasi dimana pelaku bisnis dapat mengirimkan gambar sampel ataupun desain produk kepada konsumen.
Kendala/Hambatan Dalam Mengadopsi ECommerce

Adapun kendala yang dihadapi oleh pelaku bisnis UKM dalam menerapkan e-commerce dengan memanfaatkan teknologi informasi (internet) dalam kegiatan bisnisnya dapat ditunjukkan dalam rangkuman tabel 2. Kendala utama terletak pada faktor kemampuan dan keterampilan dari sumber daya manusia yang dimiliki. Berdasarkan hasil observasi dan wawancara yang dilakukan kepada sejumlah responden dapat dijelaskan bahwa secara ratarata SDM berlatar belakang pendidikan setingkat SMA dengan tingkat usia rata-rata diatas 40 tahun dan mereka belum memilki bekal pengetahuan dan keterampilan teknologi informasi yang memadahi. Bahkan untuk level pekerja (pengrajin) mayoritas belum mengenal dan mengetahui cara pemanfaatan internet. Penguasaan terhadap penggunaan internet mayoritas adalah pemimpin UKM dengan penguasaan keterampilan yang bersifat umum (pada taraf pemula), seperti mencari informasi bisnis dengan google dan berkomunikasi dengan konsumen melalui e-mail. Dengan adanya kendala tersebut, pelaku bisnis UKM menyadari bahwa penerapan e-commerce belum dapat dimanfaatkan secara maksimal. Sedangkan bagi minoritas UKM yang tidak menganggap SDM sebagai faktor kendala karena pimpinan/pemilik UKM telah memiliki kemampuan dan keterampilan yang memadahai dalam pemenafaatan internet untuk mendukung kegiatan bisnisnya.

Tabel 1: Tujuan Penggunaan Internet Dalam Kegiatan Bisnis UKM

\begin{tabular}{lcc}
\hline \multicolumn{1}{c}{ Tujuan Penggunaan Internet } & Jumlah UKM & Persentase \\
\hline Sarana komunikasi dengan pelaku bisnis & 24 & $70,6 \%$ \\
Pencarian informasi bisnis & 33 & $97,1 \%$ \\
Pemasaran produk & 16 & $47,1 \%$ \\
Transaksi bisnis secara on-line & 7 & $20,6 \%$ \\
\hline
\end{tabular}

Sumber: Data Primer yang diolah

Tabel 2: Kendala Mengadopsi E-Commerce

\begin{tabular}{lcc}
\hline \multicolumn{1}{c}{ Kendala Mengadopsi e-commerce } & Jumlah UKM & Persentase \\
\hline Keterbatasan Biaya & 18 & $52,9 \%$ \\
Keterbatasan kemampuan SDM & 24 & $70,6 \%$ \\
Keterbatasan sarana Teknologi Informasi & 21 & $61,8 \%$ \\
Ketidaksiapan UKM & 8 & $23,5 \%$ \\
Kurangnya minat UKM & 10 & $29,4 \%$ \\
Kurangnya peran/dukungan pemerintah/ swasta & 17 & $50 \%$ \\
Tidak ada tuntutan dari konsumen/pemasok & 7 & $20,6 \%$ \\
\hline
\end{tabular}

Sumber: Data Primer yang diolah 
Keterbatasan sarana dan prasarana teknologi informasi juga dinilai responden sebagai faktor yang menghambat dalam penerapan $e$ commerce. Hal ini dikarenakan sejumlah UKM belum memiliki piranti untuk dapat berkoneksi dengan jaringan internet disamping itu masih ada UKM yang belum memiliki piranti komputer yang memadahi. Beradasrkan hasil observasi dan wawancara dapat dijelaskan bahwa pelaku bisnis UKM mengakses internet untuk mendukung kegiatan bisnisnya sebagian besar dengan menggunakan piranti modem dan ada pula yang terkoneksi langsung dengan jaringan telpon di tempat usaha (seperti: speedy) serta ada yang menggunakan jasa warnet.

Keterbatasan biaya menjadi kendala terkait dengan pengadaan sarana dan prasarana teknologi informasi serta keterbatasan dana untuk mengikutsertakan SDM dalam kegiatan pelatihan penguasaan teknologi informasi. Kurangnya dukungan dari instansi pemerintah/swasta juga dinilai menjadi kendala, hal ini dikarenakan adanya harapan dari pelaku bisnis UKM bahwa semestinya instansi pemerintah/swasta yang terkait dengan pengembangan UKM memberikan penyuluhan dan pelatihan tentang teknologi informasi ataupun e-commerce kepada pelaku bisnis UKM. Dengan demikian UKM dapat menyadari peran penting teknologi informasi dalam kegiatan bisnis serta memiliki keterampilan dan pengetahuan yang memadahi dalam menggunakan internet untuk mendukung kegiatan bisnis. Berdasarkan hasil wawancara dapat diketahui bahwa belum ada pendidikan dan pelatihan di bidang teknologi informasi yang bersifat intensif yang dapat memberikan bekal secara mencukupi bagi pelaku bisnis UKM. Kendala lainnya yang bersifat minoritas yang dihadapi oleh pelaku bisnis UKM adalah kurangnya minat
UKM, ketidaksiapan UKM dan kurangnya tuntutan dari konsumen dan supplier.

\section{Manfaat Pengadopsian E-Commerce}

Adapun manfaat yang diperoleh pelaku bisnis UKM dalam mengadopsi e-commerce dalam pelaksanaan kegiatan bisnisnya dapat dapat ditunjukkan pada tabel 3 .

Berdasarkan hasil wawancara dengan pelaku bisnis UKM dapat dijelaskan bahwa dengan memanfaatkan internet dalam kegiatan bisnisnya atau dengan penerapan e-commerce, mayoritas pelaku bisnis UKM dapat dengan segera mengakses informasi yang dibutuhkan dengan cepat dan tidak terbatas pada waktu serta dapat memperoleh informasi sebanyak mungkin sesuai dengan yang dibutuhkan dari berbagai sumber. Secara umum informasi bisnis yang diakses seperti: informasi penyelenggaraan pameran ataupun even promosi lainnya, informasi pasar dan produk. E-commerce juga memberikan manfaat dalam memperluas jangkauan pemasaran, pengenalan produk dan meningkatkan intensitas komunikasi dengan mitra bisnis. Manfaat ini diperoleh pelaku bisnis UKM pada taraf pemula dengan memanfaatkan e-mail sedangkan pada taraf yang lebih tinggi seperti transactor dilakukan UKM dengan memanfaatkan blog UKM ataupun menginduk pada website komersial. Sebagian pelaku bisnis UKM menilai bahwa e-commerce mampu meningkatkan kinerja bisnis terutama dalam hal efisiensi waktu dan kecepatan memperoleh informasi sehingga mempermudah UKM dalam mengatur kegiatan usahanya. Secara minoritas pelaku bisnis UKM merasakan manfaat $e$ commerce dalam hal mempermudah untuk menembus pasar global, efisiensi biaya, mempercepat transaksi bisnis on-line, dan meningkatkan daya saing bisnis.

Tabel 3: Manfaat Mengadopsi e-commerce

\begin{tabular}{lcc}
\hline \multicolumn{1}{c}{ Manfaat Mengadopsi e-commerce } & Jumlah UKM & Persentase \\
\hline Mempercepat akses informasi & 29 & $85,3 \%$ \\
Meningkatkan intensitas komunikasi antar pelaku bisnis & 12 & $35,3 \%$ \\
Memperluas jangkauan pemasaran & 28 & $82,4 \%$ \\
Mempermudah pengenalan produk & 24 & $70,6 \%$ \\
Meningkatkan daya saing UKM & 3 & $8,8 \%$ \\
Mempermudah menembus pasar global & 5 & $14,7 \%$ \\
Mempercepat transaksi bisnis on-line & 4 & $11,8 \%$ \\
Meningkatkan efisiensi bisnis & 5 & $14,7 \%$ \\
Meningkatkan kinerja bisnis secara menyeluruh & 8 & $23,5 \%$ \\
\hline
\end{tabular}




\section{Penilaian terhadap Faktor-Faktor yang Mempengaruhi Pengadopsian E-Commerce}

Berdasarkan hasil analisis deskriptif penilaian UKM terhadap faktor-faktor yang mempengaruhi pengadopsian e-commerce disajikan pada tabel 4.

\section{Penilaian Terhadap Pengadopsian E- commerce}

Adapun penilaian pelaku bisnis UKM terhadap pengadopsian e-commerce dapat ditunjukkan dalam tabel 5.

Tabel 4: Penilaian Terhadap Faktor-Faktor yang Mempengaruhi Pengadopsian E-Commerce

\begin{tabular}{|c|c|}
\hline Dukungan Organisasional & Mean \\
\hline UKM memiliki kecukupan dukungan finansial untuk menerapkan $e$-commerce & 3,50 \\
\hline UKM siap menerima resiko yang ditimbulkan dari pemanfaatan $e$-commerce & 3,62 \\
\hline Ada komitmen dari pimpinan UKM untuk menerapkan e-commerce & 3,68 \\
\hline Adamya kesadaran UKM untuk menerima perubahan dan perkembangan teknologi informasi & 3,76 \\
\hline Kompetensi Teknologi & Mean \\
\hline $\begin{array}{l}\text { Kemampuan dan keterampilan SDM dalam menggunakan Teknologi Informasi dinilai biasa atau } \\
\text { belum pada tahap yang memadahi/trampil }\end{array}$ & 3,35 \\
\hline Ketersediaan piranti teknologi informasi (komputer dan jaringan internet) cukup memadahi & 3,71 \\
\hline $\begin{array}{l}\text { Ketersediaan program dan system pendukung e-commerce (software, website) dinilai mencukupi } \\
\text { meskipun dalam kapasitas yang terbatas }\end{array}$ & 3,40 \\
\hline $\begin{array}{l}\text { Kesesuaian antara manfaat dan biaya serta kerumitan dalam penerapan e-commerce dinilai netral } \\
\text { dalam artian UKM belum memberikan perhatian khusus terhadap perbandingan antara manfaat dan } \\
\text { biaya }\end{array}$ & 3,38 \\
\hline Lingkungan eksternal & Mean \\
\hline $\begin{array}{l}\text { Adanya dorongan dan tuntutan dari konsumen memotivasi UKM untuk menggunakan e-commerce } \\
\text { dalam kegiatan bisnisnya }\end{array}$ & 3,50 \\
\hline $\begin{array}{l}\text { Adanya dorongan dan tuntutan dari pemasok untuk menggunakan e-commerce dinilai netral oleh } \\
\text { UKM. Dalam artian belum memberikan dampak yang berarti bagi UKM untuk mengadopsi } e \text { - } \\
\text { commerce }\end{array}$ & 3,26 \\
\hline $\begin{array}{l}\text { UKM menilai adanya perkembangan dunia bisnis mendorong UKM untuk menggunakan } e \text {-commerce } \\
\text { dalam kegiatan bisnisnya }\end{array}$ & 3,94 \\
\hline $\begin{array}{l}\text { UKM menilai netral terhadap dorongan dan tuntutan dari pemerintah atau instansi terkait untuk } \\
\text { menggunakan } e \text {-commerce dalam kegiatan bisnisnya. }\end{array}$ & 3,03 \\
\hline $\begin{array}{l}\text { UKM menilai netral terhadap dorongan dan tuntutan dari pesaing yang bergerak pada industri sejenis } \\
\text { dan pada skala usaha yang sama untuk menggunakan } e \text {-commerce. }\end{array}$ & 3,03 \\
\hline
\end{tabular}

Sumber: Data Primer yang diolah

Tabel 5: Penilaian Terhadap Pengadopsian E-commerce

\begin{tabular}{lc}
\hline \multicolumn{1}{c}{ Kesediaan Pengadopsian E-Commerce } & Mean \\
\hline UKM menilai dalam mengadopsi $e$-commerce didukung oleh seluruh elemen organisasi & 3,97 \\
UKM menilai cukup tersedia sumber daya sesuai dengan kemampuan dan kapasitas UKM untuk & 3,88 \\
mengadopsi $e$-commerce meskipun dalam tingkatan yang sederhana & 3,88 \\
UKM menilai cukup tersedia sarana dan prasarana teknologi informasi untuk mengadopsi $e$ - & 3,32 \\
commerce meskipun ada sebagian yang bukan milik UKM sendiri & 3,88 \\
Dorongan dari lingkungan/pihak eksternal dinilai netral dalam memberikan pengaruh bagi pelaku \\
UKM untuk mengadopsi $e$-commerce \\
UKM mengadopsi $e$-commerce karena dinilai mempermudah akses informasi yang dibutuhkan dalam \\
kegiatan bisnis \\
UKM mengadopsi $e$-commerce karena dapat memberikan manfaat meningkatkan kinerja usaha \\
UKM mengadopsi $e$-commerce karena dapat meningkatkan kualitas dan kecepatan layanan pada \\
mitra bisnis. Umumnya hal ini didukung dengan memanfaatkan komunikasi melalui e-mail dengan \\
mitra bisnis. \\
UKM mengadopsi $e$-commerce karena dinilai mampu meningkatkan efisiensi biaya dalam kegiatan \\
usahanya, seperti: biaya pencarian informasi, biaya komunikasi, biaya promosi ataupun pemasaran \\
produk. \\
UKM mengadopsi $e$-commerce karena dinilai mampu memperoleh manfaat bisnis yang lebih besar \\
dibanding perdagangan berbasis konvensional. Hal ini terutama dalam kegiatan pencarian informasi \\
bisnis, komunikasi dengan mitra bisnis maupun pemasaran produk
\end{tabular}




\section{Pengujian Hipotesa dan Pembahasan}

Tabel 6: Hasil Analisis Regresi dan Pengujian Hipotesa

\begin{tabular}{|c|c|c|c|c|c|}
\hline \multirow[t]{2}{*}{ Model } & \multicolumn{2}{|c|}{ Unstandardized Coefficients } & \multirow{2}{*}{$\begin{array}{c}\text { Standardized } \\
\text { Coefficients } \\
\text { Beta }\end{array}$} & \multirow[t]{2}{*}{$\mathrm{t}$} & \multirow[t]{2}{*}{ sig } \\
\hline & $\mathrm{B}$ & Std. Error & & & \\
\hline Konstanta & 1.524 & .385 & & 3.955 & .000 \\
\hline Dukungan Organisasi (X1) & .229 & .102 & .274 & 2.257 & .031 \\
\hline Kompetensi Teknologi (X2) & .220 & .096 & .333 & 2.286 & .029 \\
\hline Lingkungan Eksternal (X3) & .259 & .096 & .383 & 2.687 & .012 \\
\hline $\begin{array}{l}\mathrm{R}: .789 \\
\mathrm{R}^{2}: .622 \\
\text { Adjusted } \mathrm{R}^{2}: .584 \\
\mathrm{~F}_{\text {-statistik }}: 16.452 \\
\text { Sig F }: .000 \\
\mathrm{n}: 34\end{array}$ & & & & & \\
\hline
\end{tabular}

Berdasarkan hasil analisis inferensial, maka dalam penelitian ini diperoleh hasil sebagaimana tersaji pada tabel 6 .

Berdasarkan hasil analisis regresi seperti pada tabel tersebut diatas dapat dijelaskan bahwa terdapat arah hubungan yang positip antara variabel dukungan organisasional, kompetensi teknologi dan lingkungan eksternal terhadap pengadopsian e-commerce pada UKM di Kecamatan Moyudan. Hal ini menunjukkan bahwa apabila dukungan organisasional, kompetensi teknologi dan dorongan lingkungan eksternal semakin baik maka akan semakin meningkatkan pengadopsian e-commerce oleh UKM. Tingkat keeratan hubungan antara variabel independent dan dependet menunjukkan hubungan yang erat yang ditunjukkan dari nilai koefisien korelasi berganda $(\mathrm{R})$ sebesar 0,789 . Besarnya nilai koefisien determinasi $\left(\mathrm{R}^{2}\right)$ sebesar 0,584, hal ini menunjukkan bahwa variable dukungan organisasional, kompetensi teknologi dan lingkungan eksternal memberikan kontribusi pengaruh pada variabel pengadopsian e-commerce sebesar 58,4\% sedangkan $41,6 \%$ dipengaruhi oleh variable lain yang tidak dilibatkan dalam model penelitian ini, seperti: ukuran organisasi, budaya organisasi, jenis bisnis/industri yang digeluti UKM.

Pengujian hipotesa secara parsial (Uji t) menunjukkan bahwa nilai signifikansi untuk setiap variabel penelitian lebih kecil dari $5 \%$. Hal ini menunjukkan bahwa terdapat pengaruh yang positip dan signifikan antara dukungan organisasional terhadap pengadopsian $e$ commerce pada UKM di Kecamatan Moyudan. Pembuktian hipotesis ini mendukung hasil penelitian yang dilakukan oleh Senarathna and Wickramasuriya (2011) dimana faktor organisasional seperti: budaya organisasi, karakteristik budaya dan pandangan pimpinan terhadap inovasi memiliki pengaruh yang positip terhadap pengadopsian e-commerce. Yulimar dan Setiawan (2008) menjelaskan bahwa terdapat pengaruh yang positip dari faktor organisasional seperti dukungan manajemen puncak dan kesiapan organisnasi terhadap pengadopsian $e$-commerce.

Pengujian pada pengaruh kompetensi teknologi teknologi terhadap pengadopsian $e$ commerce menunjukkan hasil yang positip dan signifikan. Pembuktian hipotesa ini mendukung hasil penelitian Azzam and Quaddus (2009), Yulimar (2006) yang menjelaskan bahwa terdapat pengaruh yang positip antara keseuaian/kecocokan penggunaan teknologi informasi bagi UKM terhadap pengadopsian $e$ commerce. Akan tetapi tingkat kerumitan pemanfaatan teknologi informasi memiliki pengaruh yang negatif terhadap pengadopsian e-commerce. Berbeda dengan hasil penelitian Almoawi and Mahmood (2010) yang menjelaskan bahwa tidak ada pengaruh dari kompatibilitas dan kompleksitas teknologi terhadap pengadopsian e-commerce.

Pengujian pada pengaruh lingkungan eksternal terhadap pengadopsian e-commerce menunjukkan hasil yang positip dan signifikan. Pembuktian hipotesis ini mendukung hasil penelitian yang dilakukan oleh Olatokun and Kebonye (2010) dimana dijelaskan bahwa dorongan dan tekanan eksternal yang ditimbulkan oleh pesaing, konsumen, mitra 
bisnis (pemasok), media dam masyarakat secara luas dapat membererikan dorongan baik secara langsung maupun tidak langsung bagi UKM untuk mengadopsi e-commerce. Dalam penelitian Almoawi and Mahmood (2010), dibuktikan bahwa faktor lingkungan yang berupa intensitas persaingan juga memberikan pengaruh yang positip pada pengadopsian $e$ commerce. Yulimar dan Setiawan (2008) menjelaskan bahwa dorongan faktor eksternal (dorongan pesaing, industri, rekan bisnis dan pemerintah) memiliki pengaruh yang positip terhadap pengadopsian e-commerce.

Dari pengujian hipotesa dengan uji $\mathrm{t}$ dapat ditunjukkan pula bahwa variable yang dominan berpengaruh terhadap pengadopsian e-commerce adalah lingkungan eksternal. Dalam penelitian ini dapat dijelaskan bahwa indikator lingkungan eksternal yang memberikan dorongan dan tekanan bagi UKM untuk mengadopsi e-commerce adalah dorongan dari konsumen dan tuntutan dari perkembangan pada dunia bisnis. Sedangkan dorongan dari pemerintah, pemasok dan pesaing pada industri sejenis dinilai belum memberikan pengaruh yang berarti bagi UKM di Kecamatan Moyudan untuk mengadopsi e-commerce.

Hasil penelitian yang dilakukan Yulimar dan Setiawan (2008) menunjukkan bahwa dorongan eksternal (pesaing, konsumen, mitra bisnis dan pemerintah) merupakan variabel yang dominan berpengaruh bagi UKM dalam mengadopsi e-commerce. Berbeda dengan penelitian Senarathna and Wickramasuriya (2011) yang menuunjukkan bahwa faktor yang dominan berpengaruh terhadap pengadopsian e-commerce adalah budaya organisasi.

Pengujian hipotesa secara simultan ditunjukkan dari hasil uji $F$ dengan nilai $F$ hitung sebesar 16,452 dengan tingkat signifikansi (p) sebesar 0,000. Hal ini menunjukan bahwa terdapat pengaruh yang positip dan signifikan antara dukungan organisasional, kompetensi teknologi dan lingkungan eksternal secara simultan terhadap pengadopsian e-commerce pada UKM di Kecamatan Moyudan. Hal ini menunjukkan bahwa semakin baik dukungan organisasi dan kompetensi teknologi yang dimiliki UKM serta semakin kuat dorongan lingkungan eksternal maka akan meningkatkan kemauan UKM untuk mengadopsi e-commerce dalam kegiatan bisnisnya.

\section{Kesimpulan}

Kendala yang dihadapi UKM di Kecamatan Moyudan dalam mengadopsi e-commerce adalah sebagai berikut: keterbatasan kemampuan SDM (70,6\%), keterbatasan saran teknologi informasi $(61,8 \%)$, keterbatasan biaya $(52,9 \%)$, kurangnya dukungan dari instansi pemerintah/swasta/lembaga terkait (50\%), kurangnya minat UKM (29,4\%), dan kurangnya tuntutan dari konsumen dan supplier $(20,6 \%)$. Adapun dari segi manfaat yang diperoleh UKM .dengan mengadopsi e-commerce meliputi: mempercepat akses informasi (85,3\%), memperluas jangkauan pemasaran $(82,4 \%)$, mempermudah pengenalan produk $(70,6 \%)$, meningkatkan intensitas komunikasi dengan mitra bisnis $(35,3 \%)$, meningkatkan kinerja bisnis secara menyeluruh $(23,5 \%)$, mempermudah untuk menembus pasar global $(14,7 \%)$, efisiensi biaya $(14,7 \%)$, mempercepat transaksi bisnis on-line $(11,8 \%)$, dan meningkatkan daya saing bisnis $(8,8 \%)$.

Pengaruh dukungan organisasional, kompetensi teknologi dan lingkungan eksternal terhadap pengadopsian e-commerce baik secara pasial maupun simultan memiliki pengaruh yang positip dan signifikan. Hal ini menunjukkan bahwa semakin baik dukungan organisasi dan kompetensi teknologi yang dimiliki UKM serta semakin kuat dorongan lingkungan eksternal maka akan meningkatkan kemauan UKM untuk mengadopsi e-commerce dalam kegiatan bisnisnya. Adapun variabel yang dominan berpengaruh tehadap pengadopsian e-commerce . adalah lingkungan eksternal. Indikator lingkungan eksternal yang memberikan dorongan dan tekanan bagi UKM untuk mengadopsi $e$ commerce adalah dorongan dari konsumen dan tuntutan dari perkembangan pada dunia bisnis.

\section{Implikasi Manajerial}

Implikasi manajerial dari hasil penelitian ini adalah perlu adanya peningkatan kesadaran bagi pelaku bisnis UKM akan arti penting pemanfaatan e-commerce dalam kegiatan bisnis. Mengingat berdasarkan hasil-hasil penelitian dapat dijelaskan bahwa pengadopsian $e$ commerce akan memberikan manfaat positip bagi peningkatan kinerja bisnis pada UKM. 
Peningkatan kesadaran dapat dilakukan dengan melibatkan pihak eksternal seperti pemerintah maupun instansi terkait untuk memberikan penjelasan atau sosialisasi mengenai e-commerce. Disamping itu dapat pula dilakukan dengan mempelajari atau melakukan monitoring terhadap aktivitas pesaing pada industri sejenis yang telah memanfaatkan e-commerce dalam kegiatan bisnisnya sehingga dapat memotivasi pelaku bisnis UKM agar lebih siap untuk berkompetisi.

Dari aspek sumber daya manusia perlu adanya peningkatan kualitas sumber daya manusia khususnya dalam penguasaan keterampilan teknologi informasi sehingga dapat semakin meningkatkan pemanfaatan teknologi informasi dalam kegiatan bisnis dan pada akhirnya dapat meningkatkan kinerja UKM. Upaya peningkatan kualitas sumber daya manusia dapat dilakukan UKM dengan mengirimkan SDM pada kegiatan-kegiatan pelatihan yang diselenggarakan oleh instansi terkait ataupun dengan mengajukan permohonan pada institusi pemerintah/swasta untuk dapat memberikan program pelatihan di bidang teknologi informasi khususnya terkait dengan perdagangan berbasis elektronik.

Terkait dengan aspek teknologi maka perlu melengkapi piranti teknologi informasi seperti komputer, jaringan internet serta pembuatan blog ataupun website guna mendukung aktivitas bisnis. Dengan piranti yang memadahi maka akan sangat mempermudah dalam melakukan transaksi bisnis dan dapat menghemat biaya. Seperti dengan memanfaatkan website UKM maka dapat menjalankan semua kegiatan bisnis secara on-line baik dalam konteks pemasaran Business to Customer maupun pada Pemasaran Busniness to Business. Kegiatan ini perlu didukung dengan adanya penyusunan rencana kegiatan dan anggaran oleh UKM untuk dapat dialokasikan pada kegiatan pengadaan perlengkapan teknologi informasi baik software maupun hardware.

\section{PENUTUP}

Adapun keterbatasan dalam penelitian ini adalah sampel penelitian yang masih terbatas jumlahnya mengingat hanya sebagian kecil UKM di Kecamatan Moyudan yang telah memanfaatkan teknologi informasi (internet) dalam kegiatan bisnisnya. Sehingga untuk penelitian selanjutnya perlu dilakukan perluasan wilayah penelitian tidak hanya sebatas pada satu kecamatan tetapi sangat dimungkinkan dalam satu kabupaten atau propinsi sehingga hasilnya akan lebih memberikan gambaran yang detail dan representatif. Disamping itu alat anasis inferensial yang digunakan sebatas pada analisis regresi (generasi pertama analisis multivariat) sehingga belum dapat menjelaskan secara detail dan menyeluruh terhadap model penelitian.

Dengan adanya keterbatasan tersebut maka perlu sekiranya peneliti memberikan rekomendasi untuk penelitian slanjutnya dengan memperluas sampel penelitian tidak hanya sebatas pada 1 kecamatan, mengingat masih terbatasnya UKM yang memanfaatkan teknologi informasi (internet) dalam kegiatan bisnisnya. Disamping itu perlunya pengembangan alat analisis misalnya dengan menggunakan Structural Equation Modeling (SEM). Teknik ini dapat dipilih karena SEM adalah generasi kedua teknik analisis multivariat yang memungkinkan peneliti untuk menguji hubungan antara variabel yang kompleks untuk memperoleh gambaran menyeluruh mengenai keseluruhan model. Selain itu, SEM juga memungkinkan pengujian sebuah rangkaian hubungan yang relatif 'rumit' secara simultan.

Untuk penelitian selanjutnya dapat dikembangkan model atau variabel penelitian dan kajian tidak hanya sebatas pada pengadopsiann e-commerce bagi UKM itu sendiri akan tetapi juga dapat diperluas untuk melakukan kajian pengadopsian e-commerce bagi UKM dalam konterks pemasaran Business to Customer (B2C) maupun Business to Business (B2B).

\section{DAFTAR PUSTAKA}

Agustina, D. 2012. 75 Ribu UKM Indonesia Memanfaatkan Internet Online. http://www. tribunews.com/2012/04/25. Diakses tanggal 7 Maret 2013.

Almoawi, A. and R. Mahmood. 2010. Applying The Role Model In Determining The E-Commerce Adoption On SME In Saudi Arabia, Asian Journal of 
Business And Management Service, 1.(7), 12-24.

Alrubaiee, L., H. Alshaibi and Y. Bayati. 2012. Relationship Between B2B eCommerce Benefits, E-Marketplace Usage and Supply Cahain Management, Global Journal of Management and Business Research. XII, June 2012

Asing., JG. Cashman., JH. Obit., J. Bolongkikit and HT. Geoffref. 2004. An Exploratory Research of the Usage Level of E-commerce among Small and Medium Enterprises (SMEs) in the West Coast of Sabah, Malaysia, http://www.handels.gu.se/ifsam/Strea ms/ etmisy/175final.pdf. Diakses tanggal 7 Maret 2013.

Azam, MS. and M. Quaaddus. 2009. Adoption of E-Commerce by The SMEs in Bangladesh: The Effect of Innovation Characteristics and Percived Risk, ANZMAC Conference-2009.

Harry. 2012. Internet Penting Buat UKM. http://www.wartaukm.com/internetpenting-buat-kembangkan-ukm, 19 Januari 2012. Diakses tanggal 7 Maret 2013.

Hunaiti, Z., R. Masa'deh and M. Mansour. 2009. Electronic Commerce Adoption Barriers in SMEs in Developing Countries: The Case of Libya, IBIMA Business Review, Vol. 2, 2009

Hussin, H. and RM. Noor. 2005. Innovating Business Throught E-Commerce: Exploring The Willingness of Malaysian SMEs. The Second International Conference on Innovations in IT.

Loudon, P. 2008. Management Information System, New Jersy. Pearson Education
Nuvriasari, A. dan U. Hadiyati. 2008. Governance di Lingkungan Usaha Kecil Menengah Studi Empiris pada Usaha Kecil Menengah di Propinsi DIY, SINERGI: Kajian Bisnis dan Manajemen, 10 (2), Juni 2008

Kabanda, S. 2011. E-Commerce Institutionalization Is Not For us: SMEs Perception of E-Commerce in Tanzania. Journal of Information System. 3 (1).

Olatokun, W. and M. Kebonye. 2010. e-Commerce Technology Adoption by SMEs in Botswana. International Journal of Emerging Technologies and Society, $8(1)$.

Purbo, OW. dan AA. Wahyudi. 2001, Mengenal e-Commerce, Jakarta. PT. Elex Media Komputindo

Salah, K. and B. Irwin. 2010. A Structural View Of E-Commerce In SMEs In Least Developing Countries, Journal 18 th Europen Conference on Information System.

Senarathna, R. and H. Wickramansuriya. 2011. Organizational Factors Affecting ECommerce Adoption In Small and Medium-Sized Enterprises, Tropical Agricultural Research, 22 (2), 204-120.

Simpson, M. and Docherty. 2004. E-Commerce Adoption Support and Advice For UK SMEs, Journal of Small Business and Enterprise Development, 11(3)

Yulimar, VA. dan A. Setiawan. 2008. Analisis Faktor-Faktor yang Mempengaruhi Pengadopsian Electronic Commerce Dan pengaruhnya Terhadap Kinerja Perusahaan (Studi Pada Perusahaan Kecil dan Menengah di Indonesia), disampaikan pada Seminar Nasional Aplikasi Sains dan Teknologi 2008 IST AKPRIND Yogyakarta. 